\title{
THE ECONOMIC CONSEQUENCES OF STATE TRADING*
}

\author{
DON D. HUMPHREY $†$
}

INTRODUCTION

By itself, the existence of state trading tells us little or nothing as to the economic consequences. If exports are sold above the domestic market price, the effect is exactly the same as a tax on exports under a regime of private trade. Similarly, if the offer price for imports is below the domestic market price, the effect is exactly the same as a tariff on imports equal to the difference between domestic and foreign prices. Throughout the present article, the analysis abstracts from transport costs.

As compared with free markets, we would normally expect a state-trading organization to attempt to reduce the cost of imports and to raise the price of its exports. But it may, conversely, buy imports above the world market price and, as in the case of American farm surpluses, sell exports below the world price. Subsidies to private trade would have similar effects. The economic consequences are determined by the price-spread that is created between domestic and foreign markets and by the state-trading price, which need not match the market price of either country.

Thus, state trading has essentially the same economic consequences as taxes and subsidies, although it may involve more blatant use of monopoly power. For one thing, it is doubtless easier to conceal precisely what happens under state trading than under the traditional forms of state intervention with free markets. For another, state trading may be used to pursue political objectives at the expense of economic gains. For example, it may be used for preclusive buying as an instrument of economic warfare, or as a means of providing foreign economic assistance.

Perhaps it might also be argued that state trading is likely to depart more radically from the free-trade position than the traditional controls of foreign trade. But this argument rests more on administrative and political considerations than on economic analysis. While it is true that governments find state trading an extremely flexible instrument for discriminating between separate markets, we should guard against mistaking this for a radical innovation, simply because the economic analysis is complex. Apart from flexibility, it seems doubtful if a country's bargaining power is increased by state trading, as compared with other forms of control. But a country willing to resort to the brutal use of economic power will find state trading a suitable instrument.

* The writer is grateful to C. E. Ferguson for helpful suggestions in the preparation of this paper.

† A.B. I929, Ohio State University; Ph.D. 1932, University of California. Professor of Economics, Duke University. Consultant, Center for International Studies, Massachusetts Institute of Technology, 1959-60. Deputy Director, Economics Division, United States Military Government, Berlin, 1946-1948. Author, American Imports (1955). Contributor to economic publications. 
State Trading Compared with Free Markets

\section{A. The Dilemma}

Uniform prices between spatially separate markets are desirable on the ground of efficiency and economic welfare. If the price of a commodity is unequal between two countries, the economic welfare of both can be increased by trading until the difference in price is eliminated. In the absence of monopoly power, private traders tend to produce this result by seeking to maximize profits. They buy in the lowpriced market and sell in the high-priced market until prices are equal.

State-trading monopolies create a dilemma because, if they follow the rule of private trade and seek to maximize profits, the economic welfare of the world is impaired by misallocation of resources. Resources are misused in this case because of undertrading as compared with the competitive volume of private trade. It will pay a state-trading organization to discriminate by buying or selling at different prices in separate markets. This is simply because state-trading organizations have enough monopoly power to influence the price by their own actions.

The objection to price discrimination from a welfare standpoint is that, typically, the exporting country's low-cost production is restricted by raising the price of its. exports, while the importing country's high-cost production is stimulated by the higher cost of imports. As a result, the pattern of consumption is distorted in both countries. These effects are the result of undertrading which yields monopoly profits. Hence, the dilemma that a state-trading monopoly must forego monopoly gains in order to avoid the undesirable effects of undertrading from a cosmopolitan. viewpoint. ${ }^{1}$

\section{B. The Effects of Undertrading}

The following analysis compares the effects of state trading with free trade under competitive conditions, since the latter is a familiar point of reference. In order to simplify the exposition, it is assumed in each case that the elasticity of demand: with respect to price is greater than zero and that supply is less than infinitely elastic.

Suppose that a state-trading monopoly attempts to reduce the cost of imports. If it offers less than the domestic price for imports:

(I) foreign consumption is stimulated,

(2) foreign production is restricted,

(3) domestic consumption is restricted, and

(4) domestic production is stimulated.

${ }^{1}$ Price discrimination is not confined to state trading, although in this case, the problem is more acute. It is not uncommon for private firms to sell exports either above or below the domestic price. In some instances, the problem is to allocate overhead costs between products which are largely exported and others which are sold chiefly in the domestic market. With a change in the composition of ouptut and conventional allocation of overhead, discrimination may be unintentional. The demand of large firms. for imports may also be important enough to influence the price. 
These economic consequences are exactly the same as the effect of a tariff on imports. The consumption and production losses from inefficient use of resources are indicated more precisely by graphic analysis at the close of the present article.

Conversely, if the government sells exports above the domestic price:

(5) foreign consumption is restricted,

(6) foreign production is stimulated,

(7) domestic consumption is stimulated, and

(8) domestic production is restricted.

The eight effects outlined above are exactly the same as the economic consequences of a tax on imports and exports equal to the spread between domestic and foreign prices. State trading will show a profit if imports are bought below domestic price or exports are sold above domestic price. That profit is equivalent to the revenue from a tax and will have the same restrictive effect on trade.

The explanation of items (3) and (4) and items (5) and (6), respectively, is that domestic price is increased by state profits on import trade and foreign price is increased by state profits on export trade. But the explanation of items ( $r$ ) and (2) and items (7) and (8) may not be equally apparent to the reader who is unaccustomed to dealing with the terms of trade. The explanation of items (I) and (2) is that the profits (tax) on state trading restrict imports and, thus, decrease the foreign price by leaving a larger supply in foreign hands. Similarly, for items (7) and (8), the profits (tax) on state trading restrict exports and lower the domestic price by leaving a larger supply in domestic hands. Just how much of the statetrading profits the foreigner can be made to pay depends on the terms of trade effect, which is discussed below under "Bargaining Power."

A country seeking the maximum advantage from state trading will discriminate also between export markets and between sources of imports. Compared with competitive bidding, it pays to offer lower prices to those countries whose export supply is inelastic and higher prices to those countries whose supply is elastic. Since a lower price in inelastic markets reduces the quantity offered only slightly, while a higher price in elastic markets increases the supply substantially, the average cost of imports is reduced by price discrimination.

Similarly, on the export side, since higher prices restrict sales very little in inelastic markets, while lower prices expand the price-sensitive market substantially, it pays to discriminate according to the elasticity of foreign import demand and charge higher prices, the more inelastic the demand.

\section{Bargaining Power}

In brief, the home country has a strong bargaining position if domestic production is a good substitute for foreign production in the home country's consumption, but a poor substitute in the foreign country's consumption, and conversely. In addition, a country's trading position is stronger (weaker), the smaller (larger) 
the additional cost of expanding its import-competing industries by shifting resources which contract its export-producing industries.

Considerable insight into the nature of this problem may be gained by reference to the terms of trade effects under competitive trading. Other things being equal, a country's bargaining power with respect to imports will be greater, the larger and more elastic its home consumption and production, and conversely. For if the cost of imports is raised against it, the contraction of its import demand will be greater, the more easily consumption can be shifted to substitute products and the more readily home production expands.

For similar reasons, the importing country's bargaining power is greater, the smaller and less elastic the foreign export supply, and conversely. For if foreign production cannot be shifted readily to other lines and foreign consumption is not responsive to a small reduction in price, the foreign country is constrained to export at less favorable terms than under the opposite conditions.

The exporting country's bargaining power is also greater, the larger and more elastic its home consumption and production. For the more readily the contraction of exports can be absorbed by consuming more and producing less at home, the greater is the country's ability to face a period of no trade, and conversely. In addition, the exporting country's bargaining power is greater, (I) the smaller its exports relative to home production, and (2) the larger its exports relative to foreign production.

It is interesting that these rules, which govern the terms of trade effects under competitive conditions, seem to be indicative, also, of the bargaining strength of statetrading monopolies. ${ }^{2}$

Now, the ultimate economic sanction is to stop trade entirely for a period rather than accept less favorable terms. As the stronger country succeeds in gaining favorable terms, its power to extract still more concessions diminishes, because complete stoppage of trade would then involve a more serious loss to the stronger country and a less serious loss to the weaker country.

In considering the trading position of two countries, the elasticity of the rest of the world's export supply may be counted as part of the importing country's bargaining strength. Similarly, the elasticity of third countries' import demand will augment the exporting country's bargaining power.

\section{An illustration}

Price discrimination and bargaining power may be illustrated by foreign trade in rubber. Since the United States now produces chemical rubber, its import demand for natural rubber is presumably more elastic than that of other manufacturing countries which produce no close substitute. Hence, if the natural-rubber-producing countries were to form a state-trading cartel, their profits could be increased by

2 See Gottfried Haberler, The Theory of International Trade 227-30 (I950); cf. J. E. Mende, Trade AND Welfare $183-85$ (I955). The present article is substantially indebted to Meade, especially the latter part of id. c. 10 . 
charging higher prices to other countries than to the United States. Moreover, the elasticity of foreign import demand for raw rubber is likely to be low. Assuming that automobile tires are the principal use of rubber, it seems unlikely, for example, that automobile sales would be appreciably restricted by a ten per cent increase in the price of raw rubber. The producing countries would have to act in concert; otherwise, the importing countries would shift their purchases to the cheapest source of supply.

Since demand for one good is a function of the price of its substitute, American consumption of chemical rubber could be reduced by lowering the price of natural rubber in the United States. The state-trading monopoly could increase profits, at least in the short run, by charging higher prices to those manufacturing countries whose import demand for natural rubber is less elastic than that of the United States. Price discrimination can be profitable so long as there are differences in the total elasticity of demand.

But in the long run, the higher price of natural rubber in other manufacturing countries would stimulate their demand for chemical rubber. They would be encouraged, by price discrimination, to import chemical rubber from the United States and to produce chemical rubber at home. In the end, the world would make too little use of its natural resources for producing natural rubber and use too much scarce capital to produce man-made rubber.

From this, it will be clear that the bargaining strength of natural-rubber-producing countries has been reduced by the advent of chemical rubber, which increases the elasticity of demand for natural rubber. Moreover, the bargaining position of natural-rubber-producing countries may be weak because (I) elasticity of homecountry demand for rubber may be zero, and (2) the supply of natural rubber is likely to be rather inelastic until producing countries are sufficiently developed to have alternative employment for their resources.

\section{Subsidized State Trading}

Thus far, we have considered state trading mainly as a means of raising the price of home-country exports and lowering the price of home-country imports. This involves undertrading as compared with the free-market volume of trade. In the opposite case, a state monopoly might overtrade, which would have the same economic effects as a subsidy to private traders.

Now, a state monopoly which paid a premium price above the free market for its imports and sold its exports below the free-market price would have economic consequences exactly opposite to the eight effects outlined above, provided always that the volume exceeded the free-market volume of trade. Thus, if a state monopoly were to expand the volume of its import trade by means of a subsidy:

(r) foreign consumption would be restricted,

(2) foreign production would be stimulated, 
(3) domestic consumption would be stimulated, and

(4) domestic production would be restricted.

This would result in misallocation of resources and distortion in the pattern of consumption which would decrease the economic welfare of the world. The effects of overtrading are symmetrical with the effects of undertrading.

It may be of interest to consider also some hybrid cases-namely, those where a subsidy does not lead to overtrading. Governments may, for noncommercial reasons, decide to subsidize trade. But this decision does not necessarily entail an expansion in the market volume of trade. In fact, a subsidy may be combined with undertrading.

One of the strident complaints heard from many parts of the world today is that the terms of trade are unfair to raw-material-producing countries. We are not concerned here with the justice of this complaint, but rather with the economic consequences of measures to assuage the new nationalism of underdeveloped countries. Except for the disposal of our farm surpluses, the United States is prone to insist on private trade at market prices, while, at the same time, we give economic assistance to underdeveloped countries. On the other hand, the Soviet Union and Communist China, as it suits their political strategy, are ready to buy raw materials at a premium above the world market price. What is the difference? ${ }^{3}$

Let us imagine, first, that the American Government were to subsidize state trading for the purpose of assisting the economic development of raw-materialproducing countries and to forestall economic penetration by the Soviet Union. Assume that the Government pays a premium price of ten per cent and imports at a loss whatever quantity is demanded by domestic buyers at the free-market price. In this case, state trading has no direct effect on foreign trade or on the use of national resources, because both the foreign and domestic market price remain unchanged. Exactly the same effect could be achieved by a foreign export tax combined with an American import subsidy to private traders. Either state trading or tax-cum-subsidy would provide foreign economic assistance, financed largely by the American income tax. Since state trading may help to avoid the stigma of inferiority often felt by the poor, the exporting country might prefer a premium price for its exports to direct financial assistance. This feeling is not so surprising when we recall that American farmers strongly prefer "fair prices," which enable them to "earn" their income by "getting it through the market," to direct subsidies by the Treasury. 4

Secondly, suppose that, after a time, the Congress refuses to continue the subsidy, but sanctions continuation of premium prices for imports. The state-trading monopoly then pays a ten per cent premium above the foreign price, but neither loses nor

\footnotetext{
${ }^{3}$ Whether or not the Soviet Union provides foreign economic assistance by paying a premium price for imports depends, obviously, on the price charged for Soviet exports.

4A more practical reason for this preference may be the diffculty of getting the Congress to vote taxes for direct subsidies, even though government support prices are equivalent to a tax on consumption.
} 
profits from raw material imports, which it resells at cost in whatever quantity the domestic market will absorb.

In this case, the effect on use of resources is exactly the same as an import tariff of ten per cent, the revenue from which is turned over to the exporting country. Such a policy would provide foreign economic aid by taxing imports. The same effect could be achieved by a foreign tax on exports (provided that America cooperated by placing a prohibitive tax on raw material imports via third countries). Thus, the difference between unsubsidized and subsidized state import trade at premium prices is that the first taxes American consumption of imports, while the second provides foreign aid, mainly, by taxing American incomes. The import tax reduces the economic welfare of the world by distorting the pattern of both consumption and production, while the income tax affects only the incentive as between work and leisure.

State-trading restrictions on raw material imports also have important indirect effects on the foreign trade between manufacturing countries. These will presently be treated by graphic analysis.

\section{America's farm surplus}

From the above, it is clear that the effect of subsidized state trading depends on whether there is undertrading or overtrading as compared with the competitive volume of trade. A simple case of overtrading because exports are priced below the world market would:

(I) stimulate foreign consumption,

(2) restrict foreign production,

(3) restrict domestic consumption, and

(4) stimulate domestic production.

But the state trading of American farm surpluses is by no means this simple. In the first place, American commercial exports are restricted by high domestic support prices coupled with acreage controls. Although farm production is not rigidly controlled, acreage allotments have been reduced as output per acre increased. Thus, both domestic and foreign consumption are initially restricted, and, in some cases, production is doubtless stimulated in third countries.

In the second place, most foreign countries protect domestic agriculture by restrictions on imports and, in some instances, by subsidies to production and exports. For these reasons, commercial exports are undertraded, compared with the freemarket volume, so that some subsidy is required to expand trade to the free-market level. This, however, is not the primary objective of the Commodity Credit Corporation. Although our domestic farm program carries an umbrella which, to some extent, protects the home production and exports of third countries, our policy is to

\footnotetext{
E Even though the mechanics of exporting farm surpluses may be delegated to private traders, they act as agents of the Commodity Credit Corporation, which owns the commodities and determines the terms on which they are sold.
} 
make every effort to dispose of America's domestic surpluses in markets and on terms which do not interfere significantly with commercial exports. ${ }^{6}$ This provides an excellent example of the administrative flexibility of state trading. It appears impractical to attempt the same thing by means of subsidies to private trade.

\section{E. Exchange Rates}

Like other departures from the free market, the effect of state trading on the use of resources cannot be evaluated without reference to the equilibrium rate of exchange for currency, which balances a country's exports and imports.

Suppose that a state-trading monopoly imports freely whatever is demanded by domestic buyers at a price ten per cent above the foreign market price, which is equivalent to a ten per cent tariff across the board. If the country's currency were initially overvalued ten per cent with fixed exchange rates, this restriction on imports would represent a step toward the equilibrium free-trade position. For if the currency were devalued to the equilibrium price, private traders would have to pay ten per cent more of their own currency to obtain the foreign exchange for each deal; this is the same as a state-trading monopoly which charges domestic buyers ten per cent above the foreign price before devaluation. In order fully to restore the equilibrium terms of trade without depreciating its overvalued currency, the state monopoly would also have to subsidize exports across the board and sell them ten per cent below domestic costs. In this sense, a debtor country whose exchange rate needs adjustment may be moving toward a free-trade position by a state-trading monopoly which subsidizes its exports and profits from its import trade.

What, in the opposite case, is the effect of a state-trading monopoly which charges a uniform ten per cent excess price above the domestic market for all its exports and undertakes to satisfy all demands for imports at a price ten per cent below the domestic market? This would have exactly the same effect as a ten per cent appreci-

\footnotetext{
o To disentangle the effect of state trading on the use of resources from broader aspects of the domestic farm program would require detailed examination, commodity by commodity, and only a few general suggestions can be offered here. In selected markets, state trading has undoubtedly increased foreign consumption. Without this discriminating export trade, domestic price supports would probably break down sooner, owing to the cost of accumulating huge domestic surpluses.

A basic question is the extent to which domestic support prices retard the shift of farm labor to more productive nonfarm employment. The answer varies so substantially between geographical areas that generalization may easily be misleading. Despite support prices, the rate of migration off farms has been impressive. Inconclusive statistical evidence suggests that migration depends more on the nonfarm demand for labor than on the level of farm prices. This implies that the return to human resources on the farm is still below the return to comparable resources in nonfarm employment.

A corollary of the domestic farm program has been a great improvement in methods of farming, so that human and capital resources are used more efficiently. But some land is farmed overintensively and is probably overvalued as a result of excessive land rents produced by acreage controls.

Finally, the criteria of economic efficiency are perfectly competitive equilibrium prices. But owing to the inelasticities of demand and supply, the free-market price is likely to diverge substantially from the long-term equilibrium. For this reason, current free-market agricultural prices may not be a very good. criterion of cconomic efficiency in areas where the farm labor supply is excessive and off-farm migration continues at impressive rates.
} 
ation of the country's currency. If we assume that trade were initially balanced and, further, that free exchange rates were allowed to preserve equilibrium trade, state trading, as prescribed above, would have no real effect whatever, because the country's currency would depreciate by ten per cent, thus offsetting exactly the effect of a uniform subsidy and export tax.8

Now, it is obvious that the essence of state trading is discrimination, rather than the uniform treatment of exports and imports. The purpose of this theoretical excursion is merely to show that with rigid exchange rates and disequilibrium trade which have commonly prevailed since the war, it is impossible to evaluate precisely the effects of ad hoc state trading. But enough has been said to indicate why state trading, as well as other restrictions and subventions, may represent a step toward, as well as a departure from, the optimum trading position from the point of view of world consumption and production.

\section{F. A Second Best}

The world is full of man-made constraints on production, consumption, and trade. We seem prone to assume that if all the optimum conditions are unattainable, the second-best choice is to attain as many as possible. This common-sense view is in error. There is no a priori basis for evaluating suboptimal alternatives. If the best is unattainable, it is not necessarily, or even probably, true that a second-best choice is one which fulfills more, rather than fewer, optimum conditions. ${ }^{9}$

When a constraint is introduced which removes one of the optimum conditions of trade, the remaining conditions for achieving the optimum are, in general, no longer desirable, even though attainable. For a second-best optimum is achieved only by introducing appropriate countervailing constraints. Moreover, a second-best solution can be achieved in many different ways, for while there is only one first best, there are many second bests.

The implication of this general theorem is, it seems, to moderate any general criticism which might be aimed at state trading, as such. The policy implied by the theory of a second best is that one market imperfection justifies another, provided the second goes as far as possible to offset the first. But this should not be construed to imply that state traders actually seek a second best, or, in fact, really know what they are doing in terms of evaluating suboptimal opportunities for trade.

'Strictly speaking, the tax and subsidy in each case would have to apply to all transactions, including invisibles as well as commodity trade.

${ }^{8}$ It may be of interest to note that profitable state import trade may have the same economic effect as profitable state export trade accompanied by adjustment of the exchange rate. If the currency is devalued $10 \%$ and a state monopoly charges a uniform profit of $10 \%$ on all cxports, the effect is exactly the same as charging a uniform profit of $10 \%$ on all imports with fixed exchange rates. Devaluation, in the first case, offsets the effect of state trading on the export terms of trade and, at the same time, raises the cost of imports by $10 \%$. This is exactly the same as the second case, in which state trading raises the cost of imports by $10 \%$. Meade makes this point, though not in connection with state trading. MEADE, op. cit. supra note 2, at 166 .

'See Lipsey \& Landcaster, The General Theory of the Second Best, 24 REv. Econ. Studies I (1956). 


\section{G. General Commodity Taxes}

Although tariffs are likely to be the more important, it is worth noting that the optimum conditions of foreign trade are not fulfilled if domestic consumption or production is taxed. A production tax is likely to restrict exports and increase imports, while a consumption tax has the opposite effects.

By increasing domestic costs of production, a production tax will (I) restrict exports as well as domestic supply, and (2) increase imports, in case of importcompeting products, since foreign costs of production do not include the tax.

The opposite effect is illustrated by American agricultural support prices, which are the equivalent of a tax on domestic consumption. They unquestionably increase export supply. Similarly, the American consumption tax on automobile tires increases export supply to the extent that it restricts domestic demand. The British tobacco tax restricts imports to the extent that it restricts domestic demand. The case of gasoline appears to be slightly more complex: an American consumption tax increases export supply, but generally higher foreign consumption taxes are likely to restrict foreign demand by a larger amount.

\section{II}

\section{A. Direct Effects}

\section{Graphic Partial Equilibrium Analysis}

We return now to a more detailed analysis of the effects of undertrading. If we assume, as in an earlier case posed, that the United States Government imports natural rubber in such quantities as to keep the domestic price ten per cent above the world price:

(I) domestic consumption of natural rubber is restricted,

(2) domestic production of chemical rubber is stimulated,

(3) the world price of rubber falls slightly, shifting the terms of trade against exporting countries, which stimulates foreign consumption in third countries, and

(4) a profit or revenue is produced on the surviving volume of imports.

These separate effects are shown clearly by graphic analysis in figure one. Qualitative differences in raw rubber are abstracted from in order to simplify the diagram. $\mathrm{DD}^{\prime}$ is aggregate American demand for raw rubber, both chemical and natural. $\mathrm{S}$ is the American supply schedule of chemical rubber. Sx is world export supply of natural rubber. ${ }^{10}$

${ }^{10} \mathrm{~A}$ flat supply curve may, perhaps, be justified for the market period of a season's harvest. This special case is introduced to simplify the initial diagram. The general case of increasing costs in all countries is shown in figure 2. By redefining the supply curves, figure 2 can easily be adapted to the present problem. 


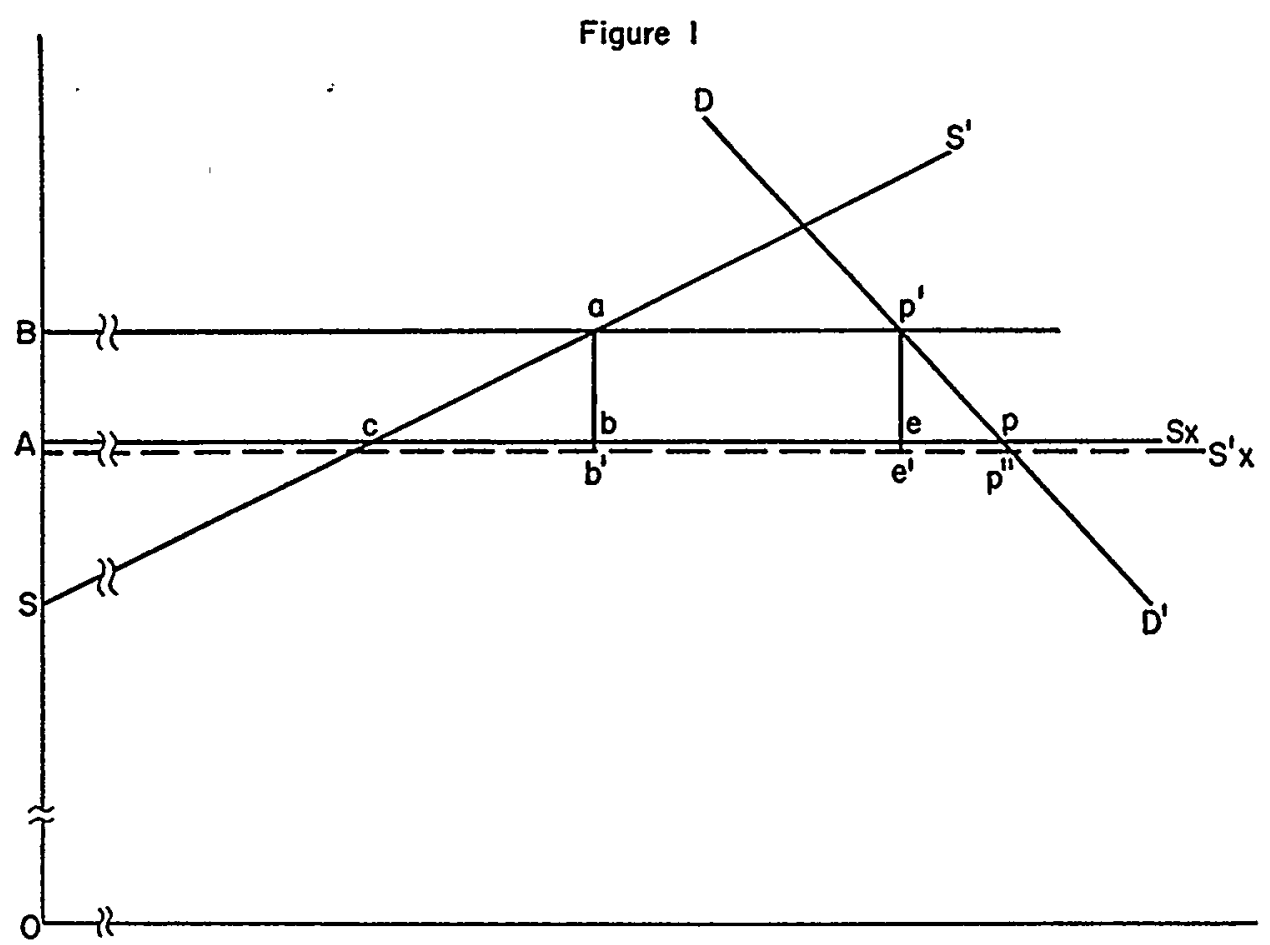

Under free trade, the price of both chemical and natural rubber is at $p$, where American demand for Ap units is satisfied by domestic production of Ac plus imports of cp. When a ten per cent price spread is introduced, the American price rises to $\mathrm{p}^{\prime}$, while world price falls to $\mathrm{p}^{\prime \prime}$. Demand is then supplied by production of Ba plus imports of ap'. Imports are reduced by cb plus ep, the productionexpanding and consumption-contracting effects, respectively. This decline of American import demand reduces the world price slightly from $\mathrm{p}$ to $\mathrm{p}$ ", the terms of trade effect. (World supply, then, becomes $S^{\prime} x$.)

In old-fashioned terms, which are simple and familiar and may, perhaps, be justified as an approximation, the production loss from less efficient use of resources is triangle abc.11 Since the area under the supply curves represents costs, triangle abc is the additional cost of substituting high-cost domestic production for imports.

Similarly, triangle p'pe represents the consumption loss, which will be developed more fully in explaining the indirect effects.

${ }^{11}$ In Marshallian analysis, starting at the free trade equilibrium price, $p$, the consumers' surplus is the area above the price line $\mathrm{Ap}$ and below the demand curve. The corresponding producers' surplus is AcS, the area above domestic costs and below the price line Ap.

At the state-trading price, $\mathrm{p}^{\prime}$, consumers' surplus is the area above the price line $\mathrm{Bp}^{\prime}$ and below the demand curve. The corresponding producers' surplus is $\mathrm{BaS}$, the area above domestic costs and below the price line $\mathrm{Bp}^{\prime}$. BacA represents a redistribution from domestic consumers to domestic producers. Rectangle ap'eb is a redistribution from consumers to revenue. This leaves triangle abe and p'pe to be explained, as above. 
Rectangle ap'e' $b$ ' is the revenue effect, the upper part of which is paid by domestic consumers, while the lower part, bee' $b$ ', is paid by foreign producers.

The production and consumption losses, abc and p'pe, respectively, will be greater, the greater the increase in price and the more sensitive are domestic production and consumption to price. On the other hand, the revenue effect will be greater, the larger the surviving volume of imports-that is, the steeper the domestic supply and demand curves.

American rubber manufacturers, faced with a ten per cent increase in the raw materials costs, would no longer stand on an equal footing with foreign manufacturers in the race for export markets. The disadvantage would restrict our exports and encourage imports of manufactured rubber products. Thus, American import demand for raw rubber would fall, owing to contraction of both domestic consumption and exports of American manufacturers. Consequently, the world price of natural rubber would decline enough to increase world consumption ${ }^{12}$ of natural rubber correspondingly. Since the United States is, in fact, an important exporter of rubber products, as well as a large importer of natural rubber, the terms of trade effect is likely to be significant.

This graphic treatment is, of course, subject to all the assumptions appropriate to partial equilibrium analysis:

(I) Since the analysis is concerned with economic efficiency, it gives no weight to redistribution effects between consumers and producers, between factors of production, or between countries.

(2) The production effect is slightly overstated if, for example, the supply curve for natural rubber shifts owing to the effect of diminishing returns on factor costs. The analysis assumes constant factor costs.

(3) The indirect effects on trade require similar analysis and may show either gains or losses.

(4) Finally, no account is taken here of the possibility of dynamic income effects nor of imperfections owing to domestic monopoly.

In sum, the direct effect of the above price changes is to stimulate American production of chemical rubber by restricting domestic consumption of natural rubber. But the indirect effect on foreign trade in manufactured rubber products works in the opposite direction. Domestic production for export would be restricted, and high-cost foreign production would expand because of an artificial advantage in raw material costs.

\section{B. Indirect Effects}

The indirect effect of higher American raw material costs on foreign trade in manufactured rubber products is shown graphically in figure two. $D$ is the import

${ }^{19}$ And eventually to decrease world production, an adjustment not shown by this special case. 
Figure 2

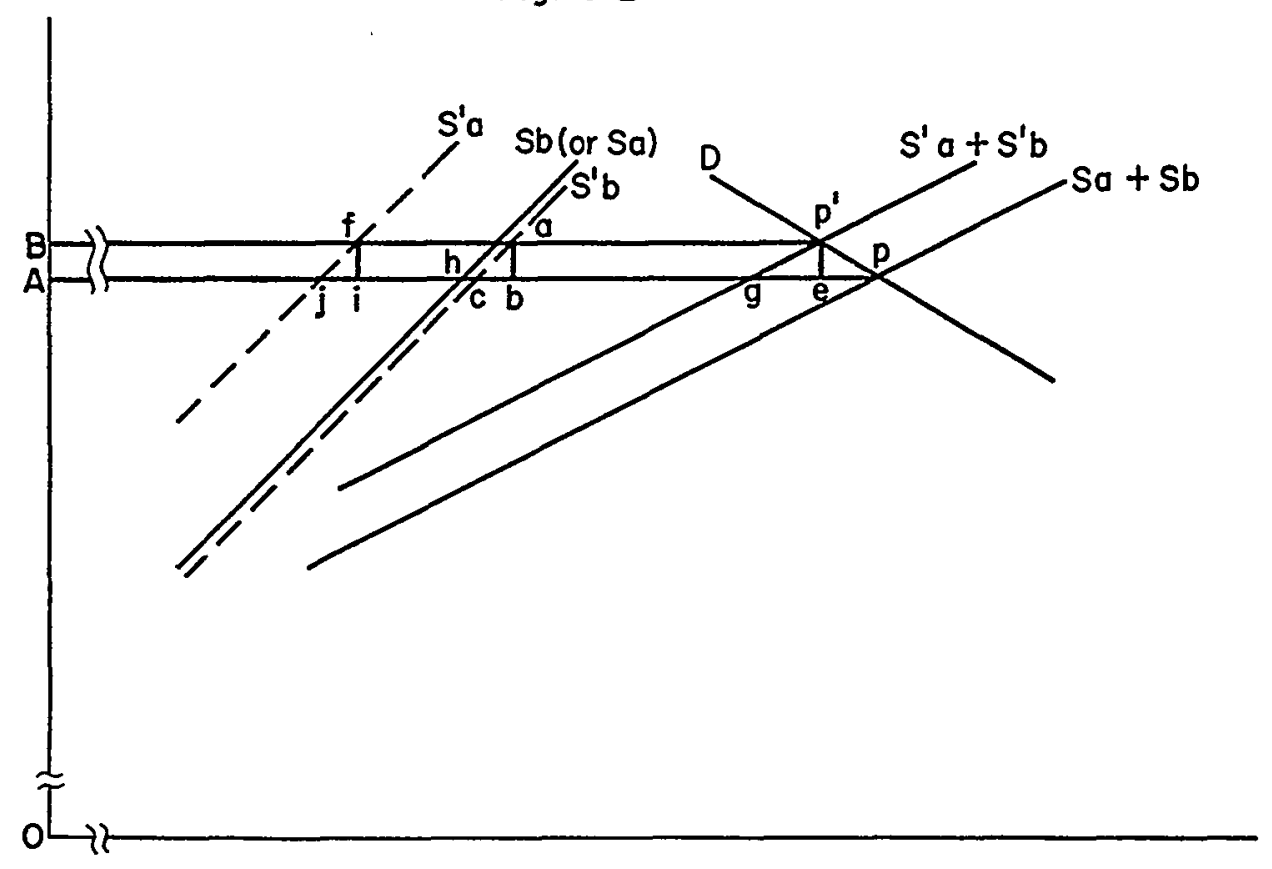

demand for rubber tires of a third country which does not produce tires. $\mathrm{Sb}$ is the British export supply, based on the international free-market cost of raw rubber. ${ }^{13}$ Under this condition, it is convenient to assume that the American export supply curve, Sa, happens to coincide exactly with that of the British, so that total supply, $\mathrm{Sa}$ plus $\mathrm{Sb}$, available to the importing third country is exactly double the supply offered by either exporting country. This does not affect the analysis and may make it easier to see at a glance that total export supply, Sa plus $\mathrm{Sb}$, is flatter than the supply curve of either country-not because of any change in costs, but simply because the total reaction to price is the sum of the two separate reactions. The aggregate supply curve, $\mathrm{Sa}$ plus $\mathrm{Sb}$, is obtained simply by adding the British and American exports (abscissae) corresponding to each price ordinate.

At the free-market cost of raw rubber, the same to both exporting countries, the third country's demand for imports of rubber tires is Ap, which is satisfied by imports of Ah from Britain plus equal imports of hp from the United States.

Introduction of higher American raw material costs shifts the American export supply curve up and to the left, as shown by the dotted line $S^{\prime}$ a. The terms of trade effect on the world price of natural rubber, already dealt with in figure one, shifts British export supply down to the right, as shown by the new supply curve, $\mathrm{S}^{\prime} \mathrm{b}$. (Note that both horizontal and vertical scales in the diagram have been broken in

${ }^{18}$ In figure 2, Sb may equally be regarded as the domestic production of an importing country. The common case of a country which imports from scveral outside sources would require adding additional supply curves to the diagram for each country. 
order to enlarge the area which shows the effects of raw material prices on foreign trade in rubber tires.)

The new equilibrium price of tires is $p^{\prime}$, where third-country demand crosses the new aggregate supply curve, $\mathrm{S}^{\prime}$ a plus $\mathrm{S}^{\prime} \mathrm{b}$. Demand of $\mathrm{Bp}^{\prime}$ is now satisfied by $\mathrm{Ba}$ imports from Britain plus ap' (=Bf) imports from the United States. Total imports are reduced by ep. But despite this, imports from Britain expand by hb, owing to the lower cost of natural rubber and the higher price of tires, hc and $c b$, respectively. Imports from America, on the other hand, contract by ih, equal to total trade contraction plus British export trade expansion, ep and hb, respectively.

Triangle p'pg is composed of the consumption effect plus the production effect, $p^{\prime} p$ and p'eg, respectively, of secondary trade contraction. ${ }^{14}$ In addition, there are redistribution effects (I) between American and British producers, and (2) from third-country consumers to producers of both countries.

The consumption effect, p'pe, is part of the loss from distorting the pattern of final consumer choice by undertrading in natural rubber. The production effect, p'eg, may be decomposed into the additional cost of producing American and British exports, fij and abc, respectively. These losses are an elaboration of, not an addition to, the consumption loss in figure one. But trade contraction in figure two would involve additional losses if rubber tires were undertraded because of taxes or price discrimination. For in that case, the social cost of imports would be less than that of domestically produced substitutes. It must be remembered that trade contraction produces a net world loss and trade expansion produces a net world gain only if the marginal value of imports exceeds marginal cost, as in figure one.

Figure two, which shows the effect of discrimination in raw materials prices on the trade of finished products, is but an example. Formally, there are sixteen possibilities which may either expand or contract secondary trade. If state trading raises the domestic price of imports and lowers the foreign price, the indirect effects are to:

(I) contract domestic exports of substitutes,

(2) contract domestic imports of complements,

(3) expand foreign exports of substitutes, and

(4) expand foreign imports of complements.

\footnotetext{
${ }^{14}$ At the initial price, $\mathrm{p}$, the consumers' surplus is the area above the price line, Ap, and below the demand curve. The corresponding producers' surplus is the area below $A p$ and above the aggregate supply curve, Sa plus Sb. At the new price, $\mathrm{p}^{\prime}$, the consumers' surplus is reduced by Bp'pA. Bp'gA represents a redistribution from consumers to producers. Producers' surplus is now the area below Bp' $^{\prime}$ and above the aggregate supply curve, $S^{\prime} a$ plus $S^{\prime} b$. This leaves the triangle $p^{\prime} p g$ to be explained, as above.

The redistribution effect, $\mathrm{Bp}^{\prime} \mathrm{gA}$, is composed of $\mathrm{BacA}$ plus $\mathrm{BfjA}$, the redistribution from third-country consumers to British and American producers, respectively. In addition, American producers lose the surplus between $S^{\prime} a$ and $S a$ which is below the price line, Ap, while British producers gain the small surplus between $\mathrm{Sb}$ and $\mathrm{S}^{\prime} \mathrm{b}$ which is below Ap.
} 
. If state trading raises the price of exports and lowers the domestic price, it will indirectly:

(5) expand domestic exports of substitutes,

(6) expand domestic imports of complements,

(7) contract foreign exports of substitutes, and

(8) contract foreign imports of complements.

Each of these eight effects are the result of undertrading.

Conversely, there may be overtrading. If a state monopoly lowers the domestic price of imports and raises the foreign price by overtrading, the indirect effects are exactly the same as items (5) to (8) above. But if a state monopoly lowers the price of exports and raises the domestic price by overtrading, the indirect effects are exactly the same as items (I) to (4) above.

In each case, if secondary trade is restricted in any way, trade expansion will produce a net world gain and trade contraction will produce a net world loss, which must be added to the primary effects. For if substitute or complementary products are undertraded, the excess marginal value of imports over cost means that secondary trade expansion is beneficial and secondary trade contraction is harmful. Conversely, in the more unusual case where secondary trade is subsidized, secondary trade expansion will produce a net world loss and secondary trade contraction a world gain. For if substitute or complementary products are overtraded so that the marginal value of exports is less than marginal cost, secondary trade expansion is harmful and secondary trade contraction is beneficial. 